\title{
Methods of Analysis for a Sustainable Production System
}

\author{
M. Otero, A. Pastor, J.M. Portela, \\ J.L. Viguera and M. Huerta \\ Department of Mechanical Engineering and \\ Industrial Design. University of Cadiz Cadiz \\ Spain
}

\section{Introduction}

A manufacturing process is the set of operations required to modify the characteristics of raw materials (Wikipedia, 2011). This transformation can be of different nature, both in shape, density, strength, size, aesthetics, etc., performing in the field of industry.

In most cases, to obtain a particular product is needed lots of individual transactions so that, depending on your point of view, we could identify both the manufacturing process from supply operations of natural resources raw material to product sales, or only those in a job with a particular machine tool.

In this way we identify the magnitude of the problem, as our analysis could include the manufacturing chain or only one stage of that chain.

Are discussed below various methods to analyze, but one of the fundamental objectives that appear common in different reference articles aim is to reduce the environmental impact of product, where our goal should be along the manufacturing cycle of life, from raw material procurement, manufacturing and even the disposal of the product once it is discarded.

The importance of the approach from a global view of the product, allowing a clear identification of all the inputs/outputs that involve environmental impact, not only limited to our production line or a particular stage of the cycle, applying environmental measures in all its manufacturing.

Complementing the global aspect which we refer in the previous section, from the point of view of the product, we find ourselves with the global, but this time from the point of view of trade, the market is not only a local authority independent, but a gear in a globalized industry.

The global aspect has forced companies to become aware of not only the search of product quality and to work safely, but to get an environmental culture, thus was born the idea of total quality and environmental management systems environment as a necessary part of management in the company, increasingly important the Environmental Management Systems and ISO 14001, as a reference for implementation.

At this point, we can guess the concept of sustainable development, based on a balanced use of natural resources, and implementation of environmental concepts in manufacturing systems throughout their life cycle. 
While the concept of sustainable development has created a new concept, the concept of sustainable manufacturing has undergone profound changes in professional disciplines, and specifically in engineering.

Engineering has seen the need to learn environmental knowledge and help respond to humans increasingly concerned and aware of environmental issues.

Of course we will see in this chapter the different definitions of a sustainable production system, but these records can provide the introductory character, to have a global perspective, before we start our development of this discipline and relatively recent boom.

\section{Objectives}

The aim of this chapter is a study on sustainable manufacturing systems, in several stages:

- $1^{\circ}$ Phase: Define what you understand the various authors of the bibliography of reference for a sustainable production system.

- $\quad 2^{\circ}$ Phase: Describe the different methods of analysis for sustainable manufacturing systems (LCA, LCIA, LCC, EDIP, etc.).

- $3^{\circ}$ Phase: Analyze the interdependencies among the different methodologies, their advantages and disadvantages, etc.

- $\quad 4^{\circ}$ Phase: Summary of the conclusions reached by the development of the chapter.

\section{Development}

As we presented in the introduction, we will understand what each of the authors of a sustainable production system, starting with first reference (Alting et al.,1998), these authors suggest that in recent years, both manufacturing industry and the culture of consumerism in which humanity has been placed in recent times is undergoing a major change due to various problems:

- Pollution and waste problem.

- Consumption of non-recyclable resources (oil, for example).

- Rapid growth in world population (which implies a growth in demand, both production and consumption).

Developed countries should be aimed at combating poverty and improving the health of the least developed countries, for it must set a target to fight because these countries have economic growth.

This mentality is slowly getting. The evidence is the aid from developed countries is limited mostly to food and supplies, that perspective is changing soon forgotten enhancing aspects such as technological development or infrastructure of the least advantaged, to ensure that economic development and can survive by themselves.

According to the authors, the definition of sustainable is becoming more common today, but is used with different meanings, and which is determined according to the appropriate group that definition.

If we take the environment of a company, sustainability criteria will be totally different if that goal comes from shareholders, customers, suppliers, employees, business locally, nationally, internally, etc. (Alting et al., 1998).

According to the study, although there are different criteria for sustainability under the entity from which they emanate, it concludes that any company have to fulfill several functions for Sustainability: 
- $\quad$ Economically sustainable.

- Socially sustainable.

- Sustainable with the environment.

These conclusions indicated by the authors and predicted the way the company which tends today to comprehensive management, integration into the structure of the company hierarchy of different objectives, which correspond to the following pillars:

- $\quad$ Quality Management (ISO 9000) $\rightarrow$ Economically sustainable.

- $\quad$ Prevention Management (OHSAS 18000) $\rightarrow$ Socially sustainable.

- $\quad$ Environmental Management (ISO 14000) $\rightarrow$ Sustainable with the environment.

We observe that although at first the term sustainability figure indicates that there is environmental sustainability, this is not the unique that influences the production environment, but has a more global character, based on the pillars mentioned above.

We could give an example, in this variety of meanings, which is the definition of sustainable process according to the Royal Spanish Academy (Real Academia Española, 2001): "You can maintain itself, as does, i.e. economic development without outside help or depletion of existing resources".

In this definition of the Spanish Royal Academy, the sustainable process goes in the direction at economic sustainability, which lacks its own resource consumption. Perhaps this definition is more directed to the environment or renewable energy clean energy, obtaining energy resources, mainly where there is no consumption of material resources, but it gets the production of energy.

\subsection{Definition of sustainable production system}

First we will analyze the different reference articles, and finally we try to agree a general definition for a sustainable production system.

\subsubsection{Alting et al., 1998}

According to the study Elements in a new industrial culture - Environmental Assessment in Product Development (Alting et al., 1998), the direction of sustainable production has been focused on manufacturing steps and phases of product distribution.

The study perspective is centered on the product life cycle:

- Raw Material Procurement.

- Manufacture.

- Distribution and product use.

The manufacturing steps and phases of product distribution can achieve great things. Prioritization by the company from manufacturing and distribution company is located in a development phase where the meet quality requirements and costs are extremely important. Currently, the industry had a concept of economic sustainability, where the flow INPUT/OUTPUT is very important, even without optimizing the resources use. The consumption of raw material and energy consumption has grown increasingly making an impact on the environment.

In this study, the authors recommend a change focus in the product life cycle, where companies must develop products from the perspective of optimizing resources and environmental impact in all life cycle phases.

The product environmental factor is a factor that is becoming more developed today, similar to development in the manufacture of products or distribution. 
The perspective of sustainable manufacturing system from the point of view of the authors must be fundamentally sustainability with the environment, both at the stage of raw material procurement, and throughout the manufacturing process and transportation, combined with sustainability social, avoiding risks to workers.

The sustainability criterion with the environment must appear from the moment of conception to the production system where the designer must take into account the conditions discussed above (client, law, economics, etc.) to its junction with following factors:

- Resources.

- Environmental Impacts (Local, Regional and Global).

- Work environment impacts (chemical, repetitive work, noise).

Only in this way we get a sustainable production system.

\subsubsection{Bley \& Behrning, 1998}

According to the study Methods for Qualitative and quantitative analysis of lubricants and contamination on Form Surfaces (Bley \& Behrning, 1998), the environment is increasing importance with the current procedures for product quality and economic viability.

Similar to the previous article (Alting et al., 1998), mentions that the success of a company has unquestionably been linked to several factors:

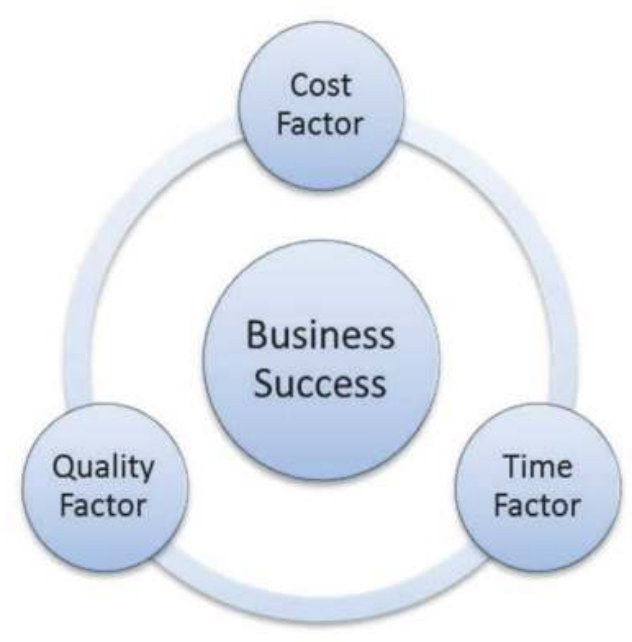

Fig. 1. Business success scheme (old)

An important factor is reflected in the study (Bley \& Behrning, 1998), are the legal restrictions, this factor greatly influences industrial, since due to new environmental regulations, which require industries to change their production system to be more sensitive to the environment.

In the document, present as an important element the use of lubricants and pollution which generate on the environment, where the current laws recommended and prohibited the use of certain substances, whether they are harmful to the environment, either because they are dangerous for use by staff working in the industry. 
The industry must adapt to the environment where it locates its manufacturing industry, legal requirements and the community significantly affects the prohibition of the use of certain products and even the need to reduce emissions of air pollutants on pain heavy fines have forced the industry to reinvent itself, including the environment sustainability for achieving business success.

The model indicated in Figure 1, to be a management model complemented by the environmental factor, such as the following:

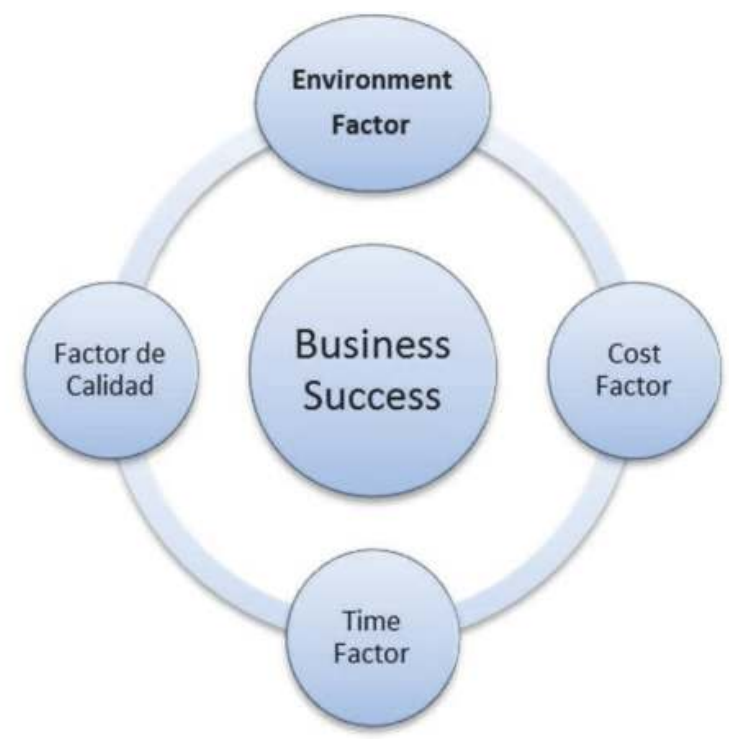

Fig. 2. Business success scheme (new)

In this case (Bley \& Behrning, 1998), are indicated factors of economic and sustainability with the environment, so you get a sustainable production system.

\subsubsection{Bley et al., 1997}

According to the study Mutual effects in a sequence of cutting and cleaning (Bley et al., 1997), displayed the same premises as in the previous article, where the environmental factor is increasing its importance on the quality standards and economic viability.

In this work not only shows the legislative factors and their influence on the production system, but also it appears a new factor, the behaviour of consumers.

Also Appears a new element today is becoming more important, the environmental image provided by the company and its relationship with consumers.

Keep in mind that any production system aims to meet the need of consumers and they are finally in the market supply will become a brand.

The concepts of quality and cost are supported as already implicit in any product that is marketed, but the products need a specific character, an item that you place over your competitors; here is where the environmental factor is a necessity imposed by society, which must be understood by the employer and integrated into manufacturing process. 
With regard to the needs imposed by society, not just about customer satisfaction, but in addition to implementing social sustainability, where the health of workers must be present in conjunction with the sustainability of the environment.

In this article appears another factor that has not been analyzed, but possibly had been included to indicate the improvement of the production process and minimizing environmental impact, which is the consideration of environmental aspects such as:

- Waste treatment.

- Product recycling.

- Verification and control system.

- Modification of manufacturing sequences.

The aim should be to structure and improve the production system, primarily to the reduction of waste generated, and later proceed to recycling and final verification. In part, this obligation is imposed by state laws, which require the improvement in the management and treatment of waste generated.

The strategy to reach a sustainable manufacturing must include analysis of all production systems individually, but sometimes it does not become possible, the problems that can generate, at least it would be important to analyze in particular the points adversely affect more critical to the process sustainability.

\subsubsection{O’Brien, 1999}

According to the study Sustainable production - a new paradigm for a new millennium (O'Brien, 1999), the concept of sustainable production is the most important element is to be developed for the S. XXI, similar to the twentieth century industrial automation and even the steam era of the nineteenth century.

As indicated in their study, the current industry is not sustainable in the long term due to excessive consumption of world natural resources. Current consumption rates, before present only in the developed world, have been taken as a model for developing countries, so the problem is not maintained, the problem increases exponentially.

There are several factors that will influence greatly in reaching a sustainable manufacturing, critical factors that threaten the economy and industrial development:

- The increase population.

- Food production.

- Industrialization.

- Depletion of natural resources.

- Contamination.

Gradually, through the twentieth century has worked in the pursuit of sustainability, achieving meet present needs without compromising future needs. This sentence clearly reflects what sustainability means.

In the twentieth century and nineteenth century there have been numerous meetings between political representatives of all nations worldwide, protected under the United Nations agency (United Nations, 2002), which have established common objectives for the pursuit of sustainability, allowing governments establish their commitment to acquire these objectives (water, education, air emissions, desertification, biodiversity, etc.)..

On a more focused, as indicated in this article (O'Brien, 1999), the industry has accepted the need to act, due largely to government law enforcement, so particular in the treatment of waste, control of air emissions, water treatment and waste transportation to landfills. 
This article appears another factor that until now had not appeared, the concept of ecoefficiency, which means a further improvement in productivity, from the economic point of view, along with a respect for the environment. The efficiency gains with the implementation of green practices.

Also appears another important concept, the factor 10, this factor represents the commitment to the objectives that governments should arrive in 2040, so if the current consumption is reduced to $10 \%$ of total resources, would continuity of ongoing development and sustainability in balance with the planet, avoiding depletion of natural resources for future generations.

For a sustainable production system (O'Brien, 1999), the author refers primarily to a sustainability with the environment, where industry must not only act as a system to create wealth but to create wealth in a sustainable way, avoiding the depletion of natural resources that are becoming scarcer, accompanied by economic sustainability, with increased efficiency, together with social sustainability, to adapt to the environment and the needs of society.

\subsubsection{Capuz \& Gomez, 2002}

According to Ecodesign - Life Cycle Engineering for Sustainable Product Development (Capuz \& Gomez, 2002), establishing a parallelism between two fundamental concepts, on the one hand the sustainable development, and on the other hand, the industrial ecology.

Sustainable development comes rather as a response to growing concerns about environmental degradation, together with the relations between human beings, caused by the characteristics of social, economic and technical, which can be described as unsustainable in the medium term.

Sustainable development aims to build a new development model that allows one hand to meet the needs of the current population of the planet, and on the other hand, preserve the environment as it is today, or even improvement. The challenge is that future generations have the same opportunities as present generations, so they can get the same quality of life that current generations.

On the one hand, the industry should respond to society and obtain in return a profit, but to do so, the industry must have a relationship with nature, eco-efficiency must extract the natural resources efficiently and sustainably.

On the other hand, citizens must accept and assume the importation of nature, taking a responsible consumption, minimize environmental impact and fair treatment to the underprivileged as well as requiring the administration to change the economic model to a model responsible, environmentally sustainable; we need a citizen participation and solidarity. These complex relationships, which link the different concepts of economic, social sustainability and environment sustainability, are reflected in the following figure:

With respect to industrial ecology, in the book (Capuz \& Gomez, 2002) is referred to the production industry in particular, as shown in the illustration above, since it identifies the industry as the main source of environmental impact.

Industrial ecology represents the model of productive activity that will contribute to realization of sustainable development, which is based on three strategies:

- Eco-efficiency.

- Environmental management.

- Eco-industrial parks. 




Fig. 3. Elements involved in sustainable development

The objective of industrial ecology is based on reaching an economic structure in which the consumption of raw materials and energy are reduced to values that the biosphere is able to replace, and waste emissions are reduced to values such that biosphere to assimilate.

We can conclude that for a sustainable production system (Capuz \& Gomez, 2002), understood from a global view, the pursuit of sustainability with the environment, avoiding a consumption rate that makes impossible its regeneration by the biosphere, trying to reach economic sustainability with the need to integrate environmental policy, together with social sustainability, where both by society and governments to impose this change in global consciousness at all levels.

\subsubsection{Goedkoop \& Spriensma, 2001}

According to the book The Eco-indicator 99 - A Damage oriented method for Life Cycle Impact Assessment (Goedkoop \& Spriensma, 2001), production and sustainable consumption can only be achieved if all business actors work responsibly.

The objective is to introduce environmental consciousness at each stage, decisions made by both the industry, the SMEs and the consumer, a process that must be in continuous development and should be encouraged and promoted by governments.

Regarding the definition of environment in the book (Goedkoop \& Spriensma, 2001) is guided by the type of damage, as can be seen in the following table:

The Eco-indicator 99 is a method of LCA (Life Cycle Assessment), especially for the design of products, and has proved a powerful tool for designers to interpret the results of the LCA, by simple numbers or units, called Eco-indicators.

We can conclude, similar to previous book (Capuz \& Gomez, 2002), which for a sustainable production system, the authors (Goedkoop \& Spriensma, 2001) understand overview, while product-oriented, in the pursuit of sustainability with the environment, led the movement 
for social sustainability, where governments and citizens are aware of the importance of environmental sustainability. Economic sustainability in this case is influenced by environmental conditions, where they accept that this process cannot be as economically beneficial for all companies and should be supported by governments through incentives.

\begin{tabular}{|c|c|c|}
\hline Object & Damage Type & Effects \\
\hline Human Health & $\begin{array}{l}\text { - Number and duration of } \\
\text { disease. } \\
\text { - Years of life lost to premature } \\
\text { death }\end{array}$ & $\begin{array}{l}\text { - } \quad \text { Climate Change. } \\
\text { - } \quad \text { Ozone Decrease. } \\
\text { - } \quad \text { Carcinogens and } \\
\text { - } \quad \text { Iospiratory Effects. }\end{array}$ \\
\hline $\begin{array}{c}\text { Quality } \\
\text { Environment }\end{array}$ & - $\quad$ Effect on species diversity. & $\begin{array}{ll}\text { - } & \text { Ecotixidad. } \\
\text { - } & \text { Acidification. } \\
\text { - } & \text { Eutrophication. } \\
\text { - } & \text { Land Use. }\end{array}$ \\
\hline Natural Resources & $\begin{array}{l}\text { - Need extra power to extract } \\
\text { resources future. }\end{array}$ & $\begin{array}{l}\text { - Decreased gross } \\
\text { resources. }\end{array}$ \\
\hline
\end{tabular}

Table 1. Effects depending on the type of damage

\subsection{7 lhobe S.A., 2000}

According to the Manual of Ecodesign - Operational Implementation in 7 steps (Ihobe S.A., 2000), it is necessary to incorporate the environmental factor in industry and society in general, this requires a change of mind on business, as in near future will be necessary to think of producing goods, preserving environmental resources and generating less waste.

Identifies three factors that significantly influenced the integration of environmental factor, such as a business factor in the design of most industrial products:

- The evolution of European and world markets.

- The evolution of environmental legislation.

- $\quad$ The end customer demand.

The benefit of minimizing environmental impacts (Ihobe S.A., 2000), is not unique, there are other advantages that should be taken into account by companies to integrate environmental philosophy into their product:

- Cost reduction, both the company and the end consumer.

- Nature of Innovation, which gives it an added attraction to the product to the final consumer.

- Comply with current legislation, both the country itself, as countries to which exports the product.

- Better meet customer demands, since the consumer himself is also acquiring sensitivity to the environmental factor.

- Increased product quality by introducing environmental factors.

- Improving product image and company, projecting a green image of company and product.

With eco-design, the approach becomes important the product life cycle, as an improvement element in the production process is not limited to manufacturing, because the producer has 
an influence on the rest of the stages of life cycle, such as the recycling facility in the end, or the use of recycled materials, once the above product has been recycled. An example can be seen in Figure 4.

We can conclude, similar to previous authors (Capuz \& Gomez, 2002; Goedkoop \& Spriensma, 2001), which for a sustainable production system, (Ihobe S.A., 2000) understand an overview of the life cycle, but also product-oriented, in the pursuit of sustainability with the environment.

\subsubsection{Curran, 2005}

According to the book Management of Environmental Quality - An International Journal (Curran, 2005), normative regulation establishes the need for incorporating environmental factors, study of the impact of products and processes throughout the product life cycle.

Contemplating the environmental impacts of products and manufacturing processes, similar to other reference material, not limited to the manufacturing phase, but all stages of product life cycle, from procurement of resources management to end once concluded.

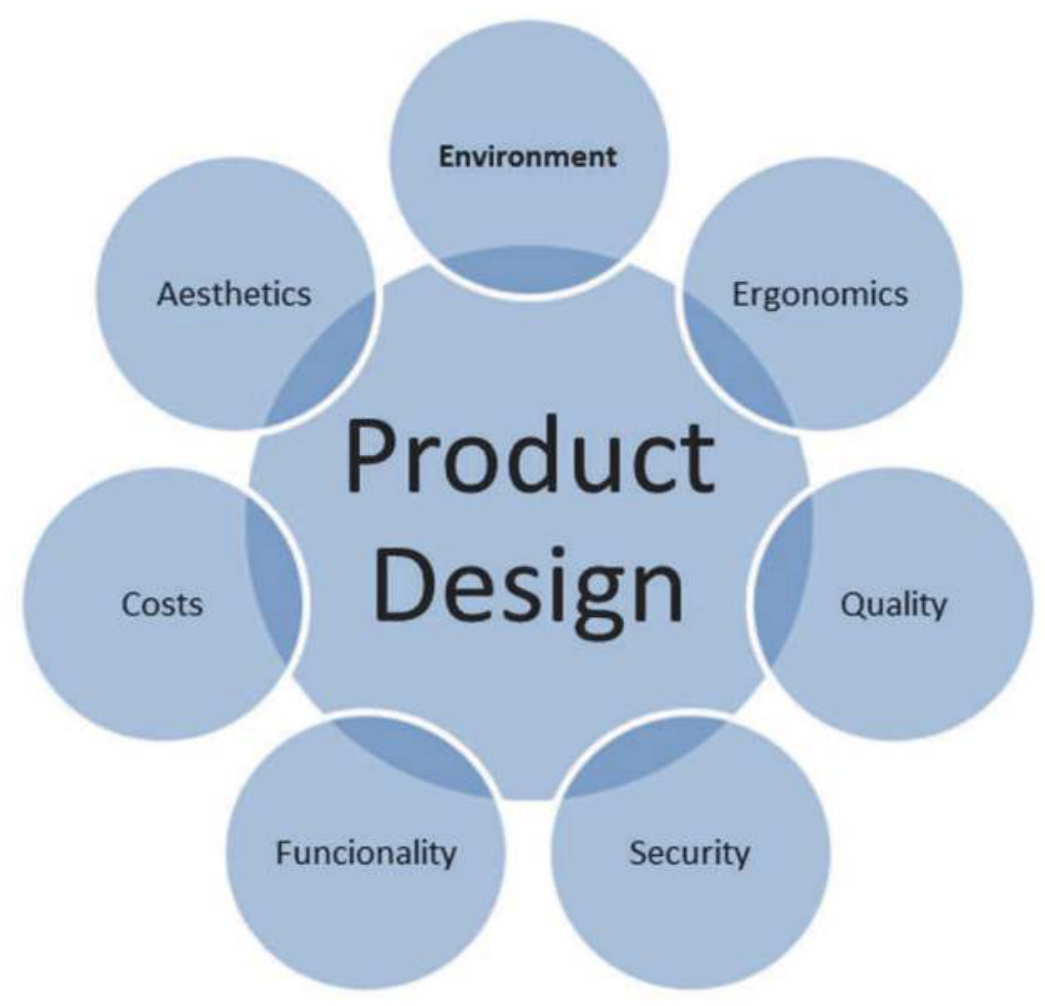

Fig. 4. Product Design

The author (Curran, 2005), like others, defines the concept of sustainability as keeping quality of life, without causing irreparable damage to the planet. 
Is reflected the trend in international forums of lectures on the life cycle concept and its use in all areas of environmental decision-making at all levels, which include for example:

- The purchasing department.

- Management policies of the company.

- Design and development of products and processes.

- Management of supply chains.

- Efficiency of buildings.

- External communications and marketing.

- Product labeling, etc.

For a sustainable production system (Curran, 2005), indicates that sustainability means an environment where the company should try to seek maintain the quality of life, without compromising future needs, integrated into all levels of the company, this will also facilitate economic sustainability, with increased efficiency, using sustainability factors in areas that cannot even seem necessary (Purchasing, marketing, etc..), so you get the social sustainability, in addition to the government law enforcement.

\subsubsection{General definition "sustainable production system"}

A sustainable manufacturing system is that the manufacturing system, usually oriented product, which has been designed by introducing environmental factors (eco-design), taking into account not only the stage of manufacturing the product, but also for all stages of the cycle of life, from the procurement of resources, until the final treatment and recycling once their useful life.

The objective that seeks a sustainable product system is mainly an environment sustainability, balance in manufacturing systems to maintain and even improve the quality of life of present generations without causing irreparable damage to the ecosystem, can be used future generations, this is the base of industrial ecology.

The origin of this evolution to the search for a sustainable product system is clearly driven by social sustainability, protection by the agencies for their workers, and the maintenance of the environment, using tools such as legislation, decisions adopted by consensus of virtually all world governments.

The integration of sustainable manufacturing must be done at a global level, at all hierarchical levels of the company where the application of sustainability factors for efficiency of the production process, achieving economic sustainability.

\subsection{Methodology for analysis of sustainable production system}

The following section describes the different methods of analysis for sustainable production systems, based on different reference articles, and later tries to make a comparative study among them.

\subsubsection{LCA methodology (Life Cycle Assessments)}

According to the study Elements in a new industrial culture - Environmental Assessment in Product Development (Alting et al., 1998), the methodology of life cycle assessment is a tool used to assess the potential environmental impact of a product, process or activity throughout their entire life cycle, by quantifying the use of INPUT resources and OUTPUT environmental emissions associated with the system being evaluated. 
According to Ecodesign - Life Cycle Engineering for Sustainable Product Development (Capuz \& Gomez, 2002), the Life Cycle Analysis is a technique for assessing environmental aspects and potential impacts associated with a product, by:

- Compiling an inventory of relevant inputs and outputs of a system.

- The assessment of potential environmental impacts associated with these inputs and outputs.

- The interpretation of the results of the phases of inventory analysis and impact assessment in accordance with the objectives of study.

The Life Cycle Assessment, according to the methodology that has finally been extended, began as a tool for assessing environmental impacts of the product and for the private use by the SETAC (Society of Environmental and Chemistry), finally the LCA has been universalized and, in order to standardize criteria and methodologies, a number of international standards have arisen, the ISO 14040 series (and a Spanish standard, the UNE 150041). Mention that the LCA study needs peer-review and the result has to be verified by independent third party (ISO 14044).

The methodology of Life Cycle Assessment is used to respond to specific questions such as:

- What resource consumption and potential effects on the environment has the product?

- What are the most important potential effects?

- Where are within the life cycle, those most important potential effects?

- What elements in the product are mainly responsible for these potential effects?

- In which stage of the product life cycle can we potentially improve the environmental issues?

The application of LCA methodology provides great advantages such as:

- Promote a detailed design change of the product, easily and with cost savings.

- Comply with existing environmental legislation, and to respond promptly to any environmental issue.

- To obtain reliable and integrated data to issue environmental reports

- To inform the public about the environmental characteristics of products and materials, improving the image of the company.

- Statistically, the application of LCA methodology has the potential for significant environmental, product quality and cost improvement.

According to the study to the study Elements in a new industrial culture - Environmental Assessment in Product Development (Alting et al., 1998), the methodology of Life Cycle Assessment (LCA), has several common elements, according to empirical studies in different companies, such as:

- The LCA methodology allows the creation of a very detailed and coherent image of the product, a detailed understanding of the life cycle, stages individually, energy consumption, resources and environmental impacts. This view allows a better understanding of the product and a most efficient performance of the solutions proposed.

- The feedback phase within the LCA methodology, either as a simulation or as a change, allows us to know more specifically the influence of these efforts on the environmental factor.

- The LCA methodology requires a considerable initial effort to obtain all necessary information, such as the knowledge of full life cycle of the product, used materials, 
manufacturing processes, operating conditions, maintenance, energy consumption, distribution and final treatment for elimination.

Regarding the analysis phases of the LCA methodology, they are defined as follows:

a. Purpose and Scope: Refers to the objective, why do it, defining the functional unit, process flow diagram or processes belonging to the system. Defining boundaries involved in the LCA.

b. Inventory: This is where you define and find the data for the LCA. It refers to the compilation of data required and it is the part that consumes more time and resources as data may come from many information sources (Industry, bibliography, Internet, databases, consultants, etc.). This chapter corresponds to the Life Cycle Inventory methodology (LCI).

c. Impact Assessment: It is the classification of issues in environmental impacts as it corresponds to the transformation of emissions of substances or molecules isolated from potential environmental impacts. This chapter corresponds to the methodology Life Cycle Impact Assessment (LCIA), discussed later on.

d. Proposals for improvement: It is the interpretation of results, where the discussion is important to analyse opportunities for improvement in the process, sensitivity analysis of results and impacts on the whole system.

\subsubsection{LCIA methodology (Life Cycle Impact Assessment)}

According to the book Management of Environmental Quality - An International Journal (Curran, 2005), the methodology for Impact Assessment Life Cycle Assessment (LCIA) is a methodology based on "indicators", where the effects of resource use and emissions generated are grouped and quantified in a limited number of impact categories that may be of weighted importance.

The methodology for Impact Assessment Life Cycle Assessment (LCIA) is part of the third phase of Life Cycle Analysis, which deals with environmental impact assessment; therefore we can say that it's the development of the third stage of (LCA), before mentioned, but due to its importance it will be analysed as an additional methodology.

According to the ISO 14040 and ISO 14042, the Environmental Impact Assessment of Life Cycle Assessment (LCIA) is essentially a tool for understanding the results of the inventory phase in LCA.

The Eco-indicator 99 is an analysis method of the product's environmental aspects and the establishment of environmental priorities, among other methods such as the Matrix MET, or software such as LCA.

The Eco-indicators are the result of a project developed by a multidisciplinary team consisting of leading industries of different sectors, scientists from independent research institutes and the Dutch government. His goal was trying to get environmental impact assessment on Environment exerts the industrial activity, focusing on the impact on the ecosystem, resources and human health.

To use the Ecoindicadores properly, the following steps must be followed:

a. Definition of the purpose to calculate the Eco-indicators.

b. Definition of Life Cycle.

c. To quantify the materials and processes.

d. To fill the form.

e. To interpret the results. 


\subsubsection{Process chain methodology}

According to the study Mutual effects in a sequence of cutting and cleaning (Bley et al., 1997), and the study Methods for Qualitative and quantitative analysis of lubricants and contamination on Form Surfaces (Bley \& Behrning, 1998), the chain process model analyses the influence of factors between different phases of a process and within them.

In the model, it is shown a main flow of material, both between processes, including the modification within them, as well as the flow of energy and secondary material flow, these are precisely the most important ones to get a more efficient and more respectful system with the environment.

This model based on processes has the great advantage that it can be considered from different points of view:

- Vertical optimization: Where the optimization of a process chain is limited to measures of optimizing an unique process, for example focusing the efforts on the process for the best efficiency of the INPUT/OUTPUT use. These measures may affect the behaviour of the process in a global way, with a reduction of the negative effects of the following stages.

- Horizontal Optimization: Contrary to the vertical optimization, in this case the optimization is not limited to a single process but is directed to the entire chain. The interrelationship between processes becomes more important and the individual process control links pass to a second stage. The disadvantage is that the complexity of the optimization increases and application of measures is much more difficult.

Usually, these optimizations are performed in parallel, in this case, combining both sequences we have two possible alternatives:

- Vertical - horizontal Optimization: This strategy is suitable for problems in which a process must be modified. In this way the process can be readjusted individually (vertical optimization), later to be adapted to the rest of the process chain (horizontal optimization).

- Horizontal - vertical Optimization: This strategy is useful when your objective is to replace a process within a process chain. The replacement of an individual process is clearly a horizontal optimization, as it must be analysed as a whole, to see how it affects the rest of the system. Once you delete that process, a vertical optimization should be applied, individually, as in this case by giving greater importance to the regulation, to the detriment of relationships, a more optimal final adjustment of the system is allowed.

\subsubsection{Process chain methodology}

According to the book Ecodesign - Life Cycle Engineering for Sustainable Product Development (Capuz \& Gomez, 2002), as a result of successive research projects carried out by the Delft University of Technology, the Dutch government published the manual PROMISE. This document was revised and completed with the collaboration of various institutes and companies and published with the United Nations Environment Programme. The reasons for the application of Ecodesign emerge from the analysis of the strengths and weaknesses of the company and the opportunities and threats present in the market. These reasons can be divided into:

- $\quad$ External Motivating factors: Management, Marketing, Environment, etc.

- Internal Motivating factors: Quality, Image, Cost Reduction, etc.

The Ecodesign methodology is divided into seven phases, which are the development of product design methodology, which are reflected in the following table: 


\begin{tabular}{|c|c|}
\hline ECO-DESIGN PHASE & STAGES OF THE METHODOLOGY \\
\hline $\begin{array}{l}\text { 1. Ecodesign Project } \\
\text { Organization. }\end{array}$ & $\begin{array}{l}\text { 1.1. Achievement of Management approval. } \\
\text { 1.2. Establishment of a project team. } \\
\text { 1.3. Make plans and prepare a budget. }\end{array}$ \\
\hline 2. $\quad$ Product Selection. & $\begin{array}{l}\text { 2.1. Establishment of selection criteria. } \\
\text { 2.2. Decision making. } \\
\text { 2.3. Define Design Report. }\end{array}$ \\
\hline $\begin{array}{l}\text { 3. Establishment of eco-design } \\
\text { strategy. }\end{array}$ & $\begin{array}{l}\text { 3.1. Analyze the product's environmental profile. } \\
\text { 3.2. Analyze the internal and external pros. } \\
\text { 3.3. Generate options for improvement. } \\
\text { 3.4. Investigate its feasibility. } \\
\text { 3.5. Defining Ecodesign strategy. }\end{array}$ \\
\hline $\begin{array}{l}\text { 4. Generation and selection of } \\
\text { ideas. }\end{array}$ & $\begin{array}{l}\text { 4.1. Generate product ideas. } \\
\text { 4.2. Organize a workshop on eco-design. } \\
\text { 4.3. Select the most promising ideas. }\end{array}$ \\
\hline 5. Details of the concept. & $\begin{array}{l}\text { 5.1. To turn ecodesign strategies into operations. } \\
\text { 5.2. Study the feasibility of the concepts. } \\
\text { 5.3. Select the most promising one. }\end{array}$ \\
\hline $\begin{array}{l}\text { 6. Communication and } \\
\text { product launch. }\end{array}$ & $\begin{array}{l}\text { 6.1. Internally promote the new design. } \\
\text { 6.2. Develop a promotional plan. } \\
\text { 6.3. Prepare production. }\end{array}$ \\
\hline $\begin{array}{l}\text { 7. Setting of follow-up } \\
\text { activities. }\end{array}$ & $\begin{array}{l}\text { 7.1. Evaluate the resulting product. } \\
\text { 7.2. Evaluate the results of the project. } \\
\text { 7.3. Develop a program of eco-design. }\end{array}$ \\
\hline
\end{tabular}

Table 2. Eco-design phases

Once the methodology and Ecodesign tools are used the product development Department should draw conclusions about which of these tools are interesting for the company and how they can be integrated into the design process of new products. For that purpose in the book Practical Guide for Ecodesign - Implementation Operative in 7 steps (Ihobe S.A., 2000), the following steps are proposed:

a. To hold a meeting within the Product Development Department, in which Ecodesign methodologies are analysed in parallel and all phases of product development at the company are also analysed, trying to integrate them.

b. To establish an action plan, at company level, this will compile the necessary changes in the product development plan, ISO 9001 or ISO 14001.

c. To proceed with the development and adjustment of the necessary tools.

\subsubsection{EDIP methodology (Environmental Design of Industrial Products)}

According to the book Ecodesign - Life Cycle Engineering for Sustainable Product Development (Capuz \& Gomez, 2002), this methodology is the result of a research program developed over 4 years by a team from the Technical University of Denmark, five Danish industrial companies, the Confederation of Danish Industries and the Environmental Protection Agency of that country.

EDIP methodology proposes the use of LCA (Life Cycle Assessment), previously described, being this the key tool to help in the decision making concerning environmental issues by the designer. Thus, while the LCA is generally considered as an environmental assessment tool, the EDIP makes an effort to adapt and integrate it into the product development process. 
As the LCA tool is considered to be the main element of the EDIP methodology, the stages of its structure coincide with the phases of the life cycle:

a. Definition of the objective and scope.

b. Inventory, where you define and find the data.

c. Categorization, where emissions of the environmental impacts are classified.

d. Interpretation of results.

For the distribution of activities with environmental significance, during the development of products, four types of design activities are identified: concretion, specification, synthesis and verification, which are reflected in following table:

\begin{tabular}{|c|c|c|}
\hline \multirow[t]{2}{*}{ TASKS } & \multicolumn{2}{|c|}{ DIVISION OF ENVIRONMENTAL WORK } \\
\hline & Specialist & Designer \\
\hline 1. Concretion & \multicolumn{2}{|c|}{ Environmental assessment of a reference product } \\
\hline \multirow[t]{3}{*}{ analysis } & $\begin{array}{l}\text { Identify potential } \\
\text { critical impact and } \\
\text { their main causes. }\end{array}$ & $\begin{array}{l}\text { Identify an existing product or an } \\
\text { imagined one as a reference for } \\
\text { the new design. }\end{array}$ \\
\hline & \multicolumn{2}{|c|}{ Environmental assessment of a reference product } \\
\hline & $\begin{array}{l}\text { - To simulate theoretical } \\
\text { changes in the } \\
\text { reference product or } \\
\text { system and thus } \\
\text { develop an LCA. } \\
\text { To develop ACL } \\
\text { specific alternatives, } \\
\text { including products } \\
\text { from the competence. }\end{array}$ & $\begin{array}{l}\text { Identify existing alternatives for } \\
\text { redesign solutions, chosen on the } \\
\text { reference product, including } \\
\text { solutions from the competence. }\end{array}$ \\
\hline diagnostics & \multicolumn{2}{|c|}{ - $\quad$ Identify key environmental issues in the relevant product. } \\
\hline \multirow[t]{2}{*}{ 2. Especification } & & Specifying environmental goals \\
\hline & & $\begin{array}{l}\text { Analyze consumer } \\
\text { environmental perceptions and } \\
\text { priorities and make a projection } \\
\text { of this analysis. } \\
\text { Define the environmental } \\
\text { specification of the product. }\end{array}$ \\
\hline \multirow[t]{2}{*}{ 3. Synthesis } & LCA of new products & Design for the environment \\
\hline & $\begin{array}{ll}\text { - } & \text { Environmental } \\
\text { assessment of } \\
\text { concepts. } \\
\text { - Environmental } \\
\text { assessment of details. }\end{array}$ & $\begin{array}{l}\text { - } \quad \text { Create environmentally attractive } \\
\text { product systems. } \\
\text { - Adapt the product } \\
\text { environmentally to existing } \\
\text { systems. } \\
\text { - If possible, adapt the system } \\
\text { environmentally to the product. }\end{array}$ \\
\hline \multirow[t]{2}{*}{ 4. Verification } & $\begin{array}{l}\text { Check the environmental } \\
\text { properties of the product }\end{array}$ & Verify design solutions \\
\hline & $\begin{array}{l}\text { - Conducting an LCA, if } \\
\text { necessary. }\end{array}$ & $\begin{array}{l}\text { - } \quad \text { Check that the environmental } \\
\text { specifications and other } \\
\text { requirements are fulfilled. }\end{array}$ \\
\hline
\end{tabular}

Table 3. Working Sharing Scheme 
Companies, usually depending of their size, can choose between training of their own personnel specialised on environment, subcontracting external consultants or assigning this activity to the designer. In this last case, it is necessary to let a specialist to regularly access to data and methods used to verify the validity of the conclusions reached.

\subsubsection{Methodology EcoReDesign}

According to the book Ecodesign - Life Cycle Engineering for Sustainable Product Development (Capuz \& Gomez, 2002), this approach led by the Centre for Design at RMIT (Melbourne), counts with the participation of EcoRecycle Victoria, the Corporation for Research and Energetic Development and the Environmental Protection Authority of New South Wales, all of the Australian institutions.

This methodology is, as its name suggests, a clear approach to redesign or improve of existing products, leading to an important task of market research on the product chosen. Consequently, it applies a more conservative approach than the EDIP methodology as, instead of introducing an environmental factor throughout the design process of a new product, it starts from an existing one to try to reduce their environmental impacts.

The redesign process or methodology adopted is structured in three phases, as contained in the following table:

\begin{tabular}{|c|c|c|}
\hline & $\begin{array}{c}\text { PHASES OF } \\
\text { ECOREDESIGN }\end{array}$ & ACTIVITIES OF THE METHODOLOGY \\
\hline & $\begin{array}{l}\text { Selection and general } \\
\text { analysis of the product. }\end{array}$ & $\begin{array}{l}\text { - Prepare a dossier with the technical, aesthetic, } \\
\text { economic and environmental characteristics of the } \\
\text { product to serve as a starting point for the next phase. } \\
\text { - Considerations of: market, competence, resources and } \\
\text { capabilities of the company, pressures or potential } \\
\text { changes, product information and its life cycle. }\end{array}$ \\
\hline 2. & $\begin{array}{l}\text { Environmental impact } \\
\text { analysis of the product } \\
\text { and establishment of } \\
\text { design directions. }\end{array}$ & $\begin{array}{l}\text { - LCA of the product or simplified assessment } \\
\text { Making a technical session of guided group work, } \\
\text { involving the departments of production, marketing, } \\
\text { environment, technical and management in order to } \\
\text { generate creative responses to the impacts identified. } \\
\text { Apply creative thinking techniques and general } \\
\text { strategies of eco-design. } \\
\text { - Critical evaluation of the value of some of the ideas } \\
\text { generated. }\end{array}$ \\
\hline & $\begin{array}{l}\text { Development of a new } \\
\text { product from a better } \\
\text { environmental aspect. }\end{array}$ & $\begin{array}{l}\text { - Classification of ideas by categories, as Figure } 8 \text { - } \\
\text { Improvement Strategies. } \\
\text { - Verification of the absence of contradictions or } \\
\text { environmental collateral impacts. }\end{array}$ \\
\hline
\end{tabular}

Table 4. Phases EcoReDesign 
The main aspect of the methodology EcoReDesign is the exploration and application of methods of life cycle assessment in order to optimize a product, when looking for technical, economic and environmental results.

The incorporation of this approach in the design process, has clearly an interdisciplinary nature, seeking a sustainable design, being this the only way to frame our product within Category 1, looking for a viable product with reference to economic, technical and with significant environmental improvements, as shown in the Figure 5.

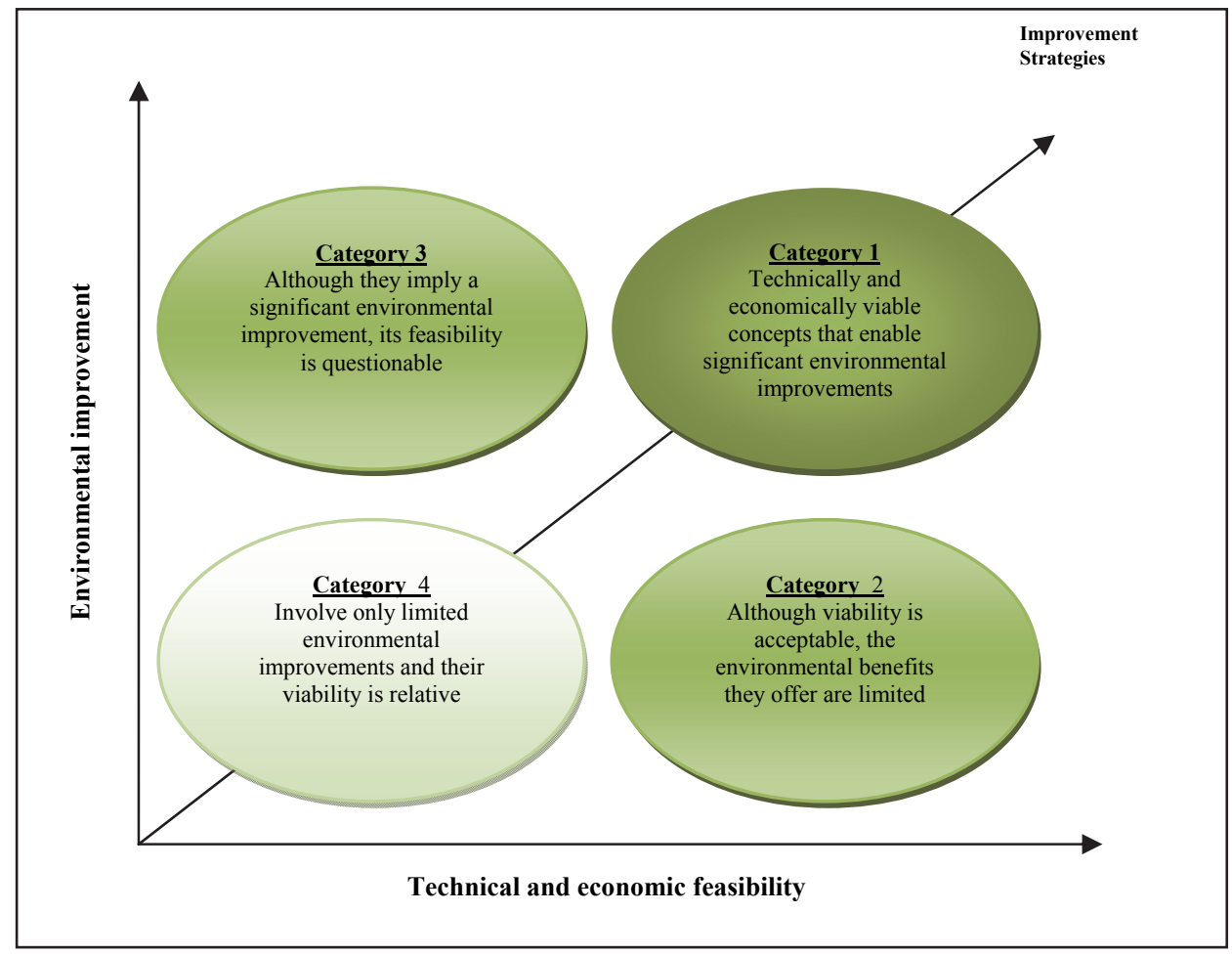

Fig. 5. Improvement Strategies (completed)

\subsubsection{Methodology LCC (Life Cycle Cost)}

The methodology of life cycle assessment (LCA) is a worldwide spread technique that allows us to identify and quantify the environmental impact of goods and services during their entire life cycle, however, the LCA methodology does not take into account financial aspects; that is why the LCC methodology (Life Cycle Cost) exists, in order to allow us to analyze both environmental and economic aspects. 
The objective of this methodology is to minimize environmental impact and to increase efficiency, reduction of cost and waste management, these are the premises to be taken into account in the search of a sustainable manufacturing.

Regarding the analysis phases of the LCC methodology, as it is based on the methodology of life LCA cycle assessment, the phases are similar, but with additional financial perspective. These phases are as follows:

a. Objective and scope: The system objectives and functional units are defined. In this case, the LCC analysis should be performed for each functional unit within the limits of the system. It is very important to define the functional unit depending on the product or process analysis.

b. Inventory: This stage involves calculation procedures and compilation of data to quantify relevant inputs and outputs of a manufacturing system. These input / outputs may include the use of resources and emissions of the system. Regarding the LCC analysis, all items or measurable variables must be related to a cost and the cost associated with system emissions generated by each functional unit.

c. Impact Assessment: This step allows us to evaluate the significance of potential environmental impacts. In general, this stage implies the association of inventory data with environmental impacts, trying to analyze those impacts. LCC analysis at this stage manages to establish a cost hierarchy, for each functional unit, and for the entire process. It is also possible to determine the contributions of larger costs for each category.

Proposals for improvement: The assessment and evaluation of proposals for improvement is the last phase. The salary supplement and the investment required will be included in this case, compressing the information of the different categories and functional units to a decision also evaluated in monetary terms.

\section{Conclusion}

It is necessary to emphasize the general definition of a sustainable production system, which is that the manufacturing system, usually product oriented, designed by introducing environmental criteria (eco-design), taking into account not only the stage of manufacturing of the product, but also considering all life cycle stages, from the obtaining of resources, to the final treatment and recycling once their function as a product is over.

The importance of the approach from a global view of the product, allows us to clearly identify all the inputs/outputs that imply an environmental impact, not only those limited to our manufacturing system or a particular stage of the cycle, but also applying environmental measures as a whole.

The objective is the search of a sustainable development, the construction of a new development model to allow the maintenance of a life quality, without causing an irreparable damage to the planet, being this the basis of the industrial ecology.

The origin of this change of perspective and the reasons that move organizations to become positively aware and set guidelines of respectful behaviour towards the environment are:

- Compliance with national, regional and local legislation.

- New business opportunities.

- Local and international competence.

- Technological development.

- $\quad$ Pressure from consumers and groups.

With regard to the different methodologies that have been treated in this chapter we can draw the followings tables 5 and 6 : 


\begin{tabular}{|c|c|c|}
\hline Methodology & Objective & Characteristics \\
\hline $\begin{array}{l}\text { Life } \\
\text { Cycle } \\
\text { Assessments } \\
\text { (LCA) }\end{array}$ & $\begin{array}{l}\text { Assess the potential environmental } \\
\text { impact of a product, process or } \\
\text { activity. } \\
\text { The decisions provoke less } \\
\text { contaminant products and with a } \\
\text { larger commitment with the } \\
\text { environment. }\end{array}$ & 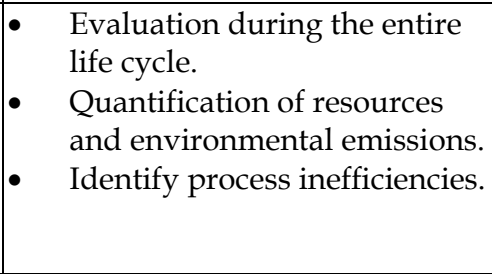 \\
\hline $\begin{array}{l}\text { Life } \\
\text { Cycle } \\
\text { Impact } \\
\text { Assessment } \\
\text { (LCIA) }\end{array}$ & $\begin{array}{l}\text { Protection of the different } \\
\text { categories of impact. } \\
\text { Ensures the maintenance of life and } \\
\text { quality of the ecosystem, without } \\
\text { reaching the adverse effects. } \\
\text { Analysis of environmental aspects } \\
\text { of a product and establishment of } \\
\text { environmental priorities. }\end{array}$ & $\begin{array}{l}\text { - Methodology based on } \\
\text { "indicators". } \\
\text { The effects of resource use } \\
\text { and emissions generated are } \\
\text { grouped and quantified. } \\
\text { Integrated in phase } 3 \text { of the } \\
\text { LCA methodology. }\end{array}$ \\
\hline $\begin{array}{c}\text { Chain } \\
\text { Processes }\end{array}$ & $\begin{array}{l}\text { Analyze the influence of factors } \\
\text { between different stages of a } \\
\text { process and within them. }\end{array}$ & $\begin{array}{l}\text { It graphically represents the } \\
\text { flow of material, not only } \\
\text { between processes, but also } \\
\text { their modification within } \\
\text { them, as well as the energy } \\
\text { flow and flow of secondary } \\
\text { materials. }\end{array}$ \\
\hline Ecodesign & $\begin{array}{l}\text { Integration of environmental } \\
\text { concept in the structure of the } \\
\text { company (organization chart and } \\
\text { procedures). }\end{array}$ & $\begin{array}{l}\text { - It is divided into } 7 \text { phases, } \\
\text { which constitute the design of } \\
\text { the product } \\
\text { - } \mathrm{t} \text { is used for the design of a } \\
\text { new product. }\end{array}$ \\
\hline EDIP & $\begin{array}{l}\text { Integration of environmental } \\
\text { concept in the process for the } \\
\text { development of the products. }\end{array}$ & $\begin{array}{l}\text { The Life Cycle Analysis } \\
\text { (LCA) is the key tool in the } \\
\text { process. } \\
\text { Need for the incorporation of } \\
\text { an environmental expert in } \\
\text { the design team. }\end{array}$ \\
\hline EcoReDesign & $\begin{array}{ll}\text { - } & \text { Focus on redesign or improvement } \\
\text { of existing products. }\end{array}$ & $\begin{array}{l}\text { A more conservative focus } \\
\text { than the EDIP methodology. } \\
\text { Main point the exploration } \\
\text { and application of methods } \\
\text { for life cycle assessment. }\end{array}$ \\
\hline $\begin{array}{l}\text { Life } \\
\text { Cycle } \\
\text { Cost } \\
\text { (LCC) }\end{array}$ & $\begin{array}{l}\text { Identify and quantify the } \\
\text { environmental and financial impact } \\
\text { of the product. }\end{array}$ & $\begin{array}{l}\text { The Life Cycle Analysis (LCA) } \\
\text { is the key tool in the process. } \\
\text { Importance of the relationship } \\
\text { between cost and } \\
\text { environment. }\end{array}$ \\
\hline
\end{tabular}

Table 5. Methodology with Objective and Characteristics 


\begin{tabular}{|c|c|c|}
\hline Methodology & Advantages & Inconveniences \\
\hline $\begin{array}{c}\text { Life } \\
\text { Cycle } \\
\text { Assessments } \\
\text { (LCA) }\end{array}$ & $\begin{array}{l}\text { - Obtain cost savings, although it is not } \\
\text { its main objective. } \\
\text { Integration of environmental criteria } \\
\text { in the organization chart of the } \\
\text { company. } \\
\text { - Wide spreading of the method (ISO } \\
\text { Standards). }\end{array}$ & $\begin{array}{l}\text { - Great effort to get all } \\
\text { information from the entire } \\
\text { life cycle. } \\
\text { - It does not consider } \\
\text { economic aspects. }\end{array}$ \\
\hline $\begin{array}{l}\text { Life } \\
\text { Cycle } \\
\text { Impact } \\
\text { Assessment } \\
\text { (LCIA) }\end{array}$ & $\begin{array}{l}\text { There is a good balance between the } \\
\text { complexity of the application of } \\
\text { different methods and interpretation } \\
\text { of the results obtained. }\end{array}$ & $\begin{array}{l}\text { A variety of methods of } \\
\text { analysis of indicators (Eco- } \\
\text { indicator 99, MET, LCA } \\
\text { software) }\end{array}$ \\
\hline $\begin{array}{l}\text { Chain } \\
\text { Processes }\end{array}$ & 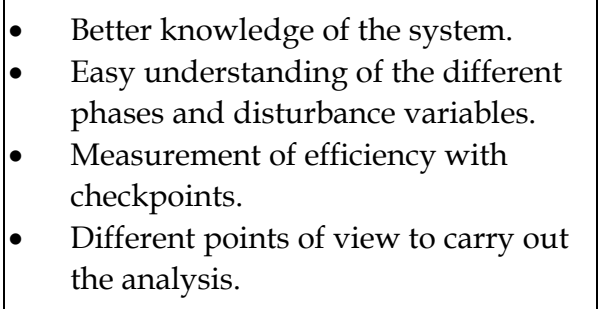 & $\begin{array}{l}\text { Previous study implies } \\
\text { great quantity of hours for } \\
\text { its preparation. }\end{array}$ \\
\hline Ecodesign & $\begin{array}{l}\text { Widespread, Integrated Programme } \\
\text { Environment United Nations. }\end{array}$ & $\begin{array}{l}\text { - Environment joins other } \\
\text { requirements (technological, } \\
\text { commercial, etc.) }\end{array}$ \\
\hline EDIP & $\begin{array}{l}\text { Complement to the LCA to assume } \\
\text { the importance of the environmental } \\
\text { factor in the company. }\end{array}$ & $\begin{array}{l}\text { - Need of qualified staff in } \\
\text { the design team: } \\
\text { Environment expert. }\end{array}$ \\
\hline EcoReDesign & $\begin{array}{l}\text { You can optimize a product, looking } \\
\text { for a better technical, economic and } \\
\text { environmental result. } \\
\text { Multidisciplinary team, looking to } \\
\text { strengthen the product from different } \\
\text { perspectives of work. }\end{array}$ & $\begin{array}{l}\text { - Not suitable in the design of } \\
\text { new products. } \\
\text { Important marketing study } \\
\text { on the product. }\end{array}$ \\
\hline $\begin{array}{l}\text { Life } \\
\text { Cycle } \\
\text { Cost } \\
\text { (LCC) }\end{array}$ & $\begin{array}{l}\text { Increase of the efficiency while } \\
\text { lowering the environmental impact. } \\
\text { Create a profitable model with } \\
\text { reference to the environmental } \\
\text { impact analysed. }\end{array}$ & $\begin{array}{l}\text { Difficulty in quantifying } \\
\text { costs in all phases of } \\
\text { product life cycle. }\end{array}$ \\
\hline
\end{tabular}

Table 6. Methodology with Advantages and Inconveniences. 
The eco-efficiency implies redesigning the manufacturing processes, using clean technologies that reduce the level of emissions, energy and resources used during manufacture, extract the natural resources efficiently and sustainably. Under the protection of the United Nations, all these concepts are to be applied worldwide.

The evolution of applying the concept of sustainable manufacturing, throughout the entire product life is becoming the reference point of any environmental management system, acquiring greater importance on quality standards and economic viability. From this, starts the idea of a total quality and environmental management systems as a necessary part of management in the company, come into scene the Environmental Management Systems and ISO 14001, as a reference for application, in addition to the rules of quality standards ISO 9001 and OHSAS 18000 occupational safety.

As a conclusion, we can say that due to the complexity, information needs and necessary resources (multidisciplinary team of environmental experts) to carry out a sustainable practice in the design / redesign of products, provides a great barrier between large companies and small and medium enterprises (SMEs).

All these methods are implemented by large companies such as automobile and electronics sectors, for example, but when we turn to the field of small and medium enterprises, the scope that can reach the application of different methods is limited to the application of ISO 14001 and the fulfilment of environmental specifications in the manufacturing chain, having little influence on the design, the obtaining of materials and their treatment at the end of their life.

Regarding the methodologies, there is a wide range, with common characteristics such as the necessity of their application in the Cycle Life of the Product as a whole, although as we have seen, their methodologies are clearly different.

Depending on the level of development, we can see that the Ecodesign methodology, protected under the United Nations program is perhaps the most classic and structured methodology, where the different phases and stages indicate the need to conduct a detailed and verified study by a team work. Even some phases which do not even exist in other methodologies are here outstanding, such as phases of communication, launching and monitoring, giving the importance of relationship with the customer as well as a feedback on the result of the project.

On the other hand, another item that frequently appears in different methodologies is the application of environmental considerations during the design of new products. We have found not many methodologies that change the target to the redesign of existing products (methodology EcoReDesign). The environmental aspect of this one is not only contemplated in new industries, but current manufacturing processes have the opportunity to improve, not remaining in the conformity of because of being older contaminant more the manufacturing process.

The application of design methodology for new products makes the impossibility of a "real" measurement of the environmental impact a product and the improvement achieved. The different methodologies are based on Eco-indicators, estimates of the influence of manufacturing processes on the environment due to their differences make it impossible the comparison between methodologies.

Despite the advantages and disadvantages of the different methodologies analysed in this dossier, it is proved the need of adjustment and preliminary study of the problem, because 
depending on the process and / or product it is more convenient to apply a different methodology.

Finally we shall mention that the application of different methodologies imply a progressive change, the integration of environmental considerations into their own company's organizational structure, adapted depending on each company, but with the same objective, the search of the model of sustainable manufacturing system.

\section{References}

Alting, L.; Haushild, M. \& Wenzel, H. (1998). Elements in a new sustainable industrial culture- Environmental assessment in product development. Robotics and Computer-Integrated Manufacturing, Vol. 14, No. issue 5-6, (October 1998), pp. (429-439), ISSN 0736-5845.

Bley, H. \& Behrning, S. (1998). Methods for qualitative and quantitative analysis of lubricants and contamination on formed surfaces, Proceedings of the Sixth Conference on Sheet Metal, pp. 343-353, ISBN 90-365-111-35, Enschede, Netherlands, April 6-8, 1998.

Bley, H.; Nickels, Th. \& Schmidt, J. (1997). Mutual effects in a sequence of cutting and cleaning, Proceedings of the 29th CIRP International Seminar on Manufacturing Systems, pp. 125-132, Osaka, Japan, May 11-13, 1997.

Capuz, S. \& Gomez, T. (2002). Ecodiseño. Ingeniería del Ciclo de Vida para el Desarrollo de Productos Sostenibles ( $1^{\mathrm{a}}$ ed.), Servicio de publicaciones Universidad Politécnica de Valencia, ISBN 8497051912, Valencia.

Curran, M.A. (2005). Management of Environmental Quality. An International Journal, Emerald Group Publishing Ltd., Retrieved from

http:/ / www.emeraldinsight.com/journals.htm?issn=14777835\&volume= $16 \& \mathrm{i}=2$

Goedkoop, M. \& Spriensma, R. (June 2001). The Eco-indicator 99. A damage oriented method for Life Cycle Impact Assessment, In: PRé Consultants, 11.04.2011, Available from http://www.pre.nl/content/reports

Ihobe S.A. (Noviembre 2000). Manual Practico de Ecodiseño. Operativa de Implantación en 7 pasos, In: IHOBE, S.A. Sociedad Pública de Gestión Ambiental. Gobierno Vasco, 11.04.2011, Available from http://www.ihobe.net/Publicaciones/Ficha.aspx ?IdMenu=750e07f4-11a4-40da-840c-0590b91bc032\&Cod=414a18ef-dd57-4b40-8746407d517f7bda\&Tipo $=$

O'Brien, C. (1999). Sustainable production - a new paradigm for a new millenium. International Journal of Production Economics, Vol. 60-61, (April 1999), pp. 1-7, ISSN 0925-5273

Real Academia Española (2001). Diccionario de la lengua española (22 ed.), Espasa-Calpe, ISBN 9788423968145, Madrid, España.

United Nations (September 2002). Plan of Implementation of the World Summit on Sustainable Development, In: United Nations web sites, 12.04.11, Available from http:// www.un-documents.net/k-001303.htm 
Wikipedia (March 2011). Proceso de Fabricacion, In: Wikipedia, 12.04.2011, Available from http://es.wikipedia.org/wiki/Proceso_de_fabricación 


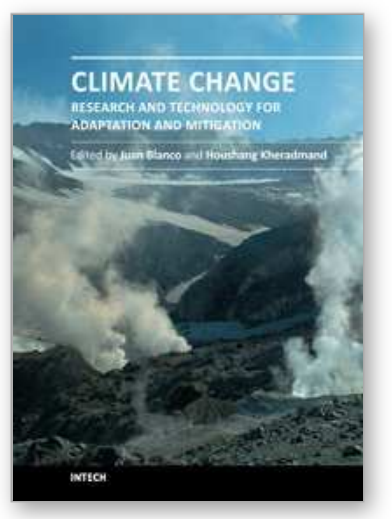

\section{Climate Change - Research and Technology for Adaptation and Mitigation}

Edited by Dr Juan Blanco

ISBN 978-953-307-621-8

Hard cover, 488 pages

Publisher InTech

Published online 06, September, 2011

Published in print edition September, 2011

This book provides an interdisciplinary view of how to prepare the ecological and socio-economic systems to the reality of climate change. Scientifically sound tools are needed to predict its effects on regional, rather than global, scales, as it is the level at which socio-economic plans are designed and natural ecosystem reacts. The first section of this book describes a series of methods and models to downscale the global predictions of climate change, estimate its effects on biophysical systems and monitor the changes as they occur. To reduce the magnitude of these changes, new ways of economic activity must be implemented. The second section of this book explores different options to reduce greenhouse emissions from activities such as forestry, industry and urban development. However, it is becoming increasingly clear that climate change can be minimized, but not avoided, and therefore the socio-economic systems around the world will have to adapt to the new conditions to reduce the adverse impacts to the minimum. The last section of this book explores some options for adaptation.

\section{How to reference}

In order to correctly reference this scholarly work, feel free to copy and paste the following:

M. Otero, A. Pastor, J.M. Portela, J.L. Viguera and M. Huerta (2011). Methods of Analysis for a Sustainable Production System, Climate Change - Research and Technology for Adaptation and Mitigation, Dr Juan Blanco (Ed.), ISBN: 978-953-307-621-8, InTech, Available from: http://www.intechopen.com/books/climate-changeresearch-and-technology-for-adaptation-and-mitigation/methods-of-analysis-for-a-sustainable-productionsystem

\section{INTECH}

open science | open minds

\section{InTech Europe}

University Campus STeP Ri

Slavka Krautzeka 83/A

51000 Rijeka, Croatia

Phone: +385 (51) 770447

Fax: +385 (51) 686166

www.intechopen.com

\section{InTech China}

Unit 405, Office Block, Hotel Equatorial Shanghai

No.65, Yan An Road (West), Shanghai, 200040, China 中国上海市延安西路65号上海国际贵都大饭店办公楼 405 单元

Phone: +86-21-62489820

Fax: +86-21-62489821 
(C) 2011 The Author(s). Licensee IntechOpen. This chapter is distributed under the terms of the Creative Commons Attribution-NonCommercialShareAlike-3.0 License, which permits use, distribution and reproduction for non-commercial purposes, provided the original is properly cited and derivative works building on this content are distributed under the same license. 